УДК 78.01

\title{
МУЗЫКАЛЬНО-ПРОСВЕТИТЕЛЬСКАЯ ДЕЯТЕЛЬНОСТЬ В РЯЗАНСКОМ ХУДОЖЕСТВЕННОМ МУЗЕЕ
}

\author{
Белякова Галина Михайловна \\ преподаватель МБУДО «ДШИ № 2» г. Рязань \\ аспирант РГУ имени С.А. Есенина
}

\begin{abstract}
Аннотация: В статье рассматривается просветительная функция музыки и обобщается опыт музыкально-просветительской деятельности в Рязанском областном художественном музее. При написании использован 35-летний практический опыт работы автора в учреждениях культуры города Рязани, который воплощался в различных использованных формах, методах и направлениях профессиональной музыкально-просветительской деятельности в учреждениях культуры Рязанского края в процессе духовно-нравственного воспитания.
\end{abstract}

Ключевые слова: искусство, концерт, культура, музей, музыка, педагогика, просвещение

\section{MUSICAL AND EDUCATIONAL ACTIVITIES IN THE RYAZAN ART MUSEUM}

\section{Belyakova Galina Mikhailovna}

\begin{abstract}
: the article discusses the educational function of music and summarizes the experience of musical and educational activities in the Ryazan regional art Museum. The author uses 35 years of practical experience of working in cultural institutions of the city of Ryazan, which was embodied in various forms, methods and directions of professional musical and educational activities in cultural institutions of the Ryazan region in the process of spiritual and moral education.
\end{abstract}

Key words: art, concert, culture, Museum, music, pedagogy, education

Как известно, музыка имеет широкое просветительное и воспитательное влияние. Просветительство же в свою очередь является одной из главных плодотворных традиций отечественной культуры. Менялись исторические 
вехи, соответственно - просветительская деятельность приобретала новые направления, решала задачи, которые диктовались особенностями социальноэкономического и культурного развития страны. Накопленный опыт музыкально-просветительской деятельности в учреждениях культуры в процессе духовно-нравственного воспитания - это наша национальная культурная традиция просветительства. Она необходима для развития, как всего общества в целом, так и отдельно взятой личности в целях совершенствования образовательного и воспитательного процессов.

В современной практике музыкальное просвещение приобрело большое значение в воспитании детей и молодежи, кроме того, давно было замечено и его положительное влияние на взрослых благодаря непосредственному воздействию на них.

В учреждениях культуры Рязанского края просветительская деятельность сопряжена с множеством функций музыки и создает необходимые условия для направления и развития нравственного воспитания подрастающего поколения, для формирования у них мировоззрения, соответствующего нормам современной жизни.

В то же время в современных условиях заметно изменяется роль и место художественных музеев в российском обществе. «Динамика его общественных и культурных функций во многом обусловлена трансформациями социокультурного и коммуникативного контекстов музейной деятельности. <..> Самоопределение и коммуникативное значение региональных музеев в значительной степени связаны с процессами их трансформации в важные центры культурной жизни» [1, с. 3]. Поэтому все более возрастает значение просветительской деятельности в музее, в том числе и посредством музыки.

В этой связи хочется поделиться практическим опытом работы, который воплощался в различных формах, методах и направлениях профессиональной музыкально-просветительской деятельности в учреждениях культуры Рязанского края в процессе духовно-нравственного воспитания и в том числе в Рязанском областном художественном музее.

Рязанский художественный музей имени И.П. Пожалостина среди достопримечательностей современной Рязани занимает особое место. Жители города называют его «Рязанская Третьяковка».

Датой рождения Рязанского областного художественного музея считается 23 марта 1915 года, когда состоялась первая выставка в городском Романовском училище (улица Семинарская). Первыми поступлениями стали 
дары московских художников и коллекция гравюр профессора Императорской Академии художеств И.П. Пожалостина. В 1918 году художественная коллекция стала частного Губернского историко-краеведческого музея. В 1938 году было решено присвоить самостоятельный статус художественному музею и разместить его в двухэтажном здании Консистории на территории Рязанского Кремля. С 1980 года музей находится в доме на улице Свободы. Это здание работы неизвестного автора предположительно из круга М.Ф. Казакова. В ХІХ веке оно принадлежало купцу Гавриле Васильевичу Рюмину и было передано его сыном Николаем Гавриловичем городу для размещения пансиона Первой мужской гимназии. В 1868 году была построена домовая церковь гимназического пансиона во имя Святителя Николая Чудотворца (освящена в 1869 году). Об этом повествуется в книге «Историческая записка Рязанской Первой мужской гимназии»», изданной в 1904 году. Здание хорошо сохранилось до наших дней, и очень хорошо соответствует назначению музея. Высокие потолки, парадная лестница, многочисленные просторные залы, красивые анфилады дают возможность сразу ощутить возвышенную, торжественную атмосферу.

Постоянную экспозицию музея ежемесячно дополняют выставки из фондов музея, также и из собраний других музеев страны, выставки современных художников, как Рязани, так и Москвы, Петербурга, других городов нашей страны. Некоторые уникальные экспонаты поступили в музей из Рязанского епархиального церковного древлехранилища. В состав коллекции входят иконы, созданные мастерами-изографами во второй половине XV века, в том числе: немногочисленные экспонаты местной художественной традиции, все эти произведения искусства объединяет калокагативность. «Калокагатийные черты имеют древние народные корни, но в такой развитой форме могли появиться они только на Руси. Свое дальнейшее развитие они получат в скульптуре XV века» [2, с. 117-119].

В Рязанском художественном музее можно увидеть древнерусское искусство - произведения статуарного характера, также полустатуарные скульптуры и просто предметы виртуозной резьбы по дереву; это «Архангел Михаил с "Чудом в Хонех" и резная икона «Архангел Михаил» (дерево), конец XV - начало XVI веков не имеющая аналогов в русской деревянной скульптуре, кроме того: Царские врата XVII века (резьбапо дереву) и т.д. [3, с. 39, 42]

Доктор искусствоведения Георгий Карлович Вагнер считает, что «средневековая русская культура на протяжении семи веков, вплоть до XVII 
века, обладала единством, параллелизмом всех составляющих ее частей. В синтез искусств наравне с зодчеством, церковной музыкой (пением), монументальной фресковой живописью, иконописью, мелкой пластикой, литературой входило и прикладное искусство» [2, с. 172].

Русская графика и живопись XVIII - XX веков - самый большой раздел собрания, начало которому было положено в самые первые годы существования музея. Далее постепенно коллекция пополнялась из Государственного музейного фонда и приобретениями у современных художников. В этой музейной коллекции отразилась история развития русской живописи периода с XVIII-XX вв. (основные стилевые направления, художественные объединения и некоторые яркие творческие индивидуальности).

«Музей в сегодняшнем его состоянии - это крупное собрание первоклассных произведений изобразительного искусства XV-XX веков. В экспозиции и фондах хранится около 12 тысяч экспонатов, многие из которых уникальны. Музей сегодня - крупное научно-исследовательское и культурнопросветительское учреждение» [3, с. 18].

В полихудожественном пространстве музея присутствуют разные виды искусства: живопись, графика, скульптура, архитектура, музыка, народноприкладное творчество, дизайн и т.д. Особенно гармонично они соединяются в выставочном зале, где проходят концерты, вечера, встречи, конференции.

Уже в 80-е годы в этом зале начали осуществляться «Декабрьские вечера», посвященные итогам уходящего года. Главное в их концепции проведение цикла музыкально - литературных встреч в пространстве значимой выставки. Различные виды искусства, раскрывая идею выставки, создают возможность многогранного проникновения в тему живописных полотен, помогают прочувствовать стиль эпохи, ее исторические, художественные, бытовые аспекты. Так, на выставке «Русский салон» (1993 г.) было проведено 11 концертов. Выступили студенты музыкального училища, одаренные ученики детских музыкальных школ, фортепианное трио (Г. Болховитина, Л. Якубовская, Т. Иванишко), гитарист В. Кузнецов, мастер художественного слова Р.А. Клейнер, артисты театров, филармонии. В 1994 г. Основную тему «Россия и Франция» обусловила выставка «Наполеон и Россия». Звучание музыкальных произведений русских и французских композиторов дополняли документы этого периода, исторические факты, воспоминания. Выставка «Кружево» Диана Смирнова (1995 г.) вызвала изысканные программы в 
исполнении пианистки С. Платоновой, ансамбля скрипачей (рук. Н.В. Панин), капеллы мальчиков (рук. О.В. Сороноумова). Особое вдохновение проявился у музыкантов выставка «Твой образ милый, незабвенный...». Великолепные женские портреты, посвящения - романсы, биографии нашли яркий эмоциональный отклик у публики. Впечатляющим был и состав исполнителей: солисты филармонии М. Чернышова, М. Башарова, Н. Белый, пианисты В. Попов, И. Ванькова, М. Харченко, артисты М. Приз, Т. Калачева.

В следующем году выставка была приурочена к 850-летию Москвы и называлась «Город чудный, город вечный...». История столицы Отечества предстала в хронологической последовательности - от основания до наших дней. Музыкальные произведения, посвященные Москве, исполнили Сергей Шулико, Ольга Калинцева, Светлана и Виктор Платоновы, Галина Разутова, Маргарита Тимофеева, Сергей Воробьев. Декабрьские вечера стали в музее традиционными, проводятся по сей день.

Еще одна постоянная форма музыкально-просветительской деятельности в музее - литературно-музыкальный концерт. Начиналась она с Пушкинских вечеров. В течение многих лет главным исполнителем является народный артист России С.М. Леонтьев. Мастерски владея искусством художественного чтения, он сумел для многих поколений раскрыть силу и красоту пушкинского слова. В концертах вместе с ним выступали певица Галина Разутова и пианистка Маргарита Тимофеева, соединяясь в уникальный ансамбль. В 90-е годы в музее состоялось концертное исполнение оперы «Евгений Онегин», главным инициатором которого был известный пианист Сергей Мартынов. Он впервые объединил рязанских исполнителей и солистов Большого театра (И. Журина, О. Бектимиров и др.). Постоянно проходят в музее литературные концерты, посвященные поэтам-землякам - С. А. Есенину и Я. П. Полонскому. Творчество Есенина представлено в программах актрисы Зои Пятницкой, ансамбля «Ока», певицы Марии Видяпиной, участников театра «Переход». Рассказ о Якове Петровиче Полонском в музее всегда воспринимается по-особому. В начале XIX века будущий писатель учился в Первой мужской гимназии города Рязани и неоднократно бывал в ее Благородном пансионе (ныне здание художественного музея). Здесь же, в 1898 году состоялось прощание с поэтом. В память о земляке в музее проходят «Пятницы Полонского». Именно так назывались вечера, некоторые устраивались в доме писателя в 80-90-е годы ХІХ века. Об этом в музее рассказывали краевед, журналист В.М. Касаткин, Н.Ф. Богданова. Стихи и романсы звучали в 
исполнении народной артистки России 3.В. Беловой, певицы Маргариты Маргуновой. Сегодня эта традиция продолжается в выступлениях Л.А. Прониной (председатель общества Полонского), певицы Натальи Нелюбиной, пианистки Елены Балашовой.

Одной из значимых форм для музея, являются интегрированные беседы концерты, раскрывающие жанровые, стилистические, языковые особенности видов искусства: «Пейзаж», «Портрет», «Под сенью дружных муз» и др. Их главный участник - пианист Евгений Антипов. Он обладает обширным репертуаром, и это позволяет включать в программы произведения самых разных композиторов. Так, в теме «Пейзаж» звучат сочинения М. Глинки, П. Чайковского, Н. Римского-Корсакого, С. Рахманинова, Л. Дакена, Ф. Шуберта, Ф. Листа, К. Сен-Санса, К. Дебюси.

Пейзажи коллекции музея после такого звучания воспринимаются с особой глубиной. Возникают художественно-звуковые параллели: тона, колорит, палитра, лад, композиция, гармония.

По-особому теплая атмосфера царит в зале, когда проходят концерты «Учитель и ученики». Эта форма соединяет в себе элементы праздничного выступления, отчетного мероприятия, родительского собрания. Возможность встретиться в возвышенно-прекрасной обстановке объединяет участников разных поколений, дарит совместную радость, снимает боязнь публичного музицирования, укрепляет семейные отношения. Также встречи постоянно проводят музыканты - педагоги Л. Ячменникова, Л. Антифеева, Е. Островская, С. Трач и др.

Уникальная акустика создает музея создает благоприятные условия для звучания хоровых произведений. Они постоянно звучат в исполнении камерного хора Рязанского государственного университета им. С.А. Есенина (художественный руководитель лауреат всероссийских и международных конкурсов Константин Михайлов).

Особую любовь слушателей заслужили вечера духовной музыки и концерты из произведений, написанных на стихи С.А. Есенина.

В течение последних 10 лет в музее проходят Рождественские вечера, которые включают: мастер-классы, театрализованные представления, концерты юных лауреатов Всероссийских и международных конкурсов. Из Бельгии каждый год в эти дни приезжает скрипачка Ольга Гай, выступлений которой с нетерпением ждут постоянные посетители. 
Сфера музыкально-просветительской деятельности при работе с детьми очень важное направление. В музее существуют прекрасные условия для проведения интегрированных занятий с детьми и молодежью. Они слышат здесь естественное, без усиления, звучание музыки, лучшие произведения литературы в исполнении мастеров, видят подлинные шедевры изобразительного искусства.

Специальные программы адресованы детям, они включают интерактивные элементы. Особой популярностью пользуются концерты оперной студии и объединения «Веселые нотки» под руководством О. Корневой. Темы: «Как дружат слово, музыка и краски», театрализованные песни, мини - оперы, импровизационное музицирование по системе Карла Орфа - эти современные методы дают возможность юным слушателям самим стать участниками музыкальных представлений.

Школьники должны не только знакомиться с шедеврами мирового искусства, но прежде всего, обретать устойчивые нравственные ориентиры, усваивать основополагающие нормы общественной жизни. Яркие представители культурно-просветительской деятельности: Б.Л. Яворский, Б.М. Неменский, Д.Б. Кабалевский в своих работах подчеркивали особую значимость синтеза искусств для развития духовно-нравственных качеств юношества. «Музей представляет собой важное воспитательное средство, так как требует от ребенка внимания, организует детский интеллект и вызывает глубокие чувства», - мнение А. Макаренко [4, с. 417].

Несомненно, звучание музыки "под сенью дружных муз" открывает широкие возможности как для исполнителей, так и для слушателей. Восприятие становится многоуровневым, возникает ассоциативный ряд, усиливается эмоциональное воздействие. Различные виды искусства взаимообогащают и взаимодополняют друг друга. В книге «Воспитание ума и сердца» Д.Б. Кабалевский писал: «Значение музыки далеко выходит за пределы искусства. Так же как литература и изобразительное искусство, музыка решительно вторгается во все области воспитания и образования, являясь могучим средством формирования духовного мира» [5, с. 27]. Однако деятельность такой направленности требует высокого уровня знаний в области педагогики и современных информационных технологий, участвующих в этом процессе.

Хочется подчеркнуть, что с 1932 по 1937 год заведующим картинной галереей музея, а в 1947 году старшим научным сотрудником Рязанского 
областного художественного музея был (в дальнейшем известный ученый, искусствовед, лауреат Государственной премии СССР) Г.К. Вагнер (1908-1995), который сделал вывод, что «архитектура, живопись, пластика и музыка функционально всегда слиты» [2, с. 171].

\section{Список литературы}

1. Макарова И. И. Российский художественный музей в современном социокультурном пространстве: стратегии и коммуникации. Автореферат диссертации на соискание ученой степени - M, 2011

2. Вагнер Г.К. Искусство Древней Руси / Г.К. Вагнер, Т.Ф. Владышевская. - М.: Искусство, 1993. - 254 с.

3. Рязанский государственный областной художественный музей имени И.П. Пожалостина: альбом / авт. вступ. ст. М.А. Котова; сост. И.Н. Денисова, С.Н. Есенина, Н.В. Павлова; пер. на англ. М.Ю. Храмовой. - Рязань: Приз, 2011. $-270 \mathrm{c}$.

4. Макаренко А.С. Педагогические сочинения: в 8 т. Том 4. Педагогические работы 1936-1939 / А. С. Макаренко; редкол. М. Кондаков и др.; Акад. пед. наук СССР. - М: Педагогика, 1984. - 398 с.

5. Кабалевский Д. Воспитание ума и сердца: Кн. для учителя - 2-е изд., испр. и доп. - М.: Просвещение, 1984. - 206 с. 